\title{
PENGARUH KECERDASAN EMOSIONAL DAN KARAKTERISTIK INDIVIDU TERHADAP MINAT BERWIRAUSAHA MAHASISWA MANAJEMEN FAKULTAS EKONOMI UNIVERSITAS TADULAKO
}

\author{
MUHAMMAD HASBY \\ IDRIS AZIS \\ ANDI INDRIANI \\ Jurusan Manajemen, Fakultas Ekonomi, Universitas Tadulako \\ Email: hasbyrizal01@gmail.com
}

\begin{abstract}
The aim of this research is to determine simultaneous and partial influence of emotional intelligence (X1) and individual characteristics (X2) on entrepreneurship interests (Y). Subject of the research is students of Management Faculty of Economics, Tadulako University of 88 students, which consists of 28 students of 2012 batch, 26 students of 2013 batch, and 34 students of 2014 batch. Data collection methods applied are observation, interviews, and questionnaires; data analysis is multiple linear regressions with SPSS software for Windows Release 16.0. The result shows that: 1) emotional intelligence and individual characteristics simultaneously have significant influence on entrepreneurship interests of students in the Faculty of Economics, Tadulako University, 2) emotional intelligence has significant influence on entrepreneurship interests of students in the Faculty of Economics, Tadulako University, and 3) individual characteristics have significant influence on entrepreneurship interests of students in the Faculty of Economics, Tadulako University.
\end{abstract}

Keywords: emotional intelligence, individual characteristics, entrepreneurship interests

\begin{abstract}
Abstrak
Penelitian ini bertujuan untuk mengetahui pengaruh secara serempak dan parsial dari Kecerdasan Emosional $\left(\mathrm{X}_{1}\right)$ dan Karakteristik Individu $\left(\mathrm{X}_{2}\right)$, terhadap Minat Berwirausaha $(\mathrm{Y})$. Subjek dalam penelitian ini adalah mahasiswa Manajemen Fakultas Ekonomi Universitas Tadulako, dengan sampel 88 orang, yang terdiri dari 28 mahasiswa manajemen angkatan 2012, 26 mahasiswa manajemen angkatan 2013 dan 34 mahasiswa manajemen angkatan 2014. Pengambilan data menggunakan metode observasi, wawancara, dan kuesioner kemudian diolah dengan menggunakan alat analisis regresi linear berganda dengan program SPSS For Windows Release 16.0. Hasil penelitian ini menunjukkan bahwa 1) Kecerdasan Emosional dan Karakteristik Individu secara serempak berpengaruh signifikan terhadap Minat Berwirausaha mahasiswa Manajemen Fakultas Ekonomi Universitas Tadulako, 2) Kecerdasan Emosional berpengaruh signifikan terhadap Minat Berwirausaha mahasiswa Manajemen Fakultas Ekonomi Universitas Tadulako, dan 3) Karakteristik Individu berpengaruh signifikan terhadap Minat Berwirausaha mahasiswa Manajemen Fakultas Ekonomi Universitas Tadulako.
\end{abstract}

Kata Kunci: Kecerdasan Emosional, Karakteristik Individu, Minat Berwirausaha

\section{PENDAhuluan}

\section{Latar Belakang Penelitian}

Masalah pengangguran masih menjadi tantangan perekonomian di Indonesia. Pengangguran atau tuna karya adalah istilah untuk orang yang tidak bekerja sama sekali, sedang mencari kerja, bekerja kurang dari dua hari selama seminggu, atau seseorang yang sedang berusaha mendapatkan pekerjaan yang layak. Pengangguran umumnya disebabkan karena jumlah angkatan kerja atau para pencari kerja tidak sebanding dengan jumlah lapangan kerja yang ada yang mampu menyerapnya. Pengangguran seringkali menjadi masalah dalam perekonomian karena dengan adanya pengangguran, produktivitas dan pendapatan masyarakat akan berkurang sehingga dapat menyebabkan timbulnya kemiskinan dan masalah-masalah sosial lainnya.

Menurut Data Badan Pusat Statistik menunjukan tingkat pengangguran terbuka (TPT) di indonesia pada Februari 2015 mencapai 5,81\%, mengalami penurunan dibanding tingkat pengangguran terbuka Agustus 2014 sebesar 5,94\% Penyerapan tenaga kerja hingga Februari 2015 
Hasby, M.

masih didominasi oleh penduduk bekerja berpendidikan rendah, yaitu SD ke bawah adalah 45,19\%. Sedangkan penduduk berpendidikan tinggi yaitu pendidikan sarjana ke atas hanya sebesar 8,29\%. Khususnya di Sulawesi Tengah tingkat pengangguran terbuka (TPT) pada Februari 2015 mencapai 2,99\%,mengalami penurunan dibanding TPT Agustus 2014 sebesar 3,68\%, namun mengalami kenaikan jika dibanding dengan TPT Februari 2014 sebesar 2,92 \%. (http://sulteng.bps.go.id, diakses tgl 8 September 2016)

Angka pengangguran yang besar dapat diperkecil salah satunya dengan cara berwirausaha. Wirausaha merupakan alternatif pilihan yang tepat untuk mengatasi pengangguran. Berwirausaha berarti membuka lapangan kerja baru dan berperan serta mengatasi masalah pengangguran. Berwirausaha adalah solusi cerdas mengatasi pengangguran dan kemiskinan di Indonesia. Diharapkan setelah lulus para mahasiswa lulusan perguruan tinggi pendidikan diploma atau sarjana memiliki kemauan dan minat berwirausaha dan mampu membuka lapangan kerja baru. Sehingga mahasiswa dapat mempekerjakan para pengangguran dan tidak selalu untuk dipekerjakan. (Setiawati, 2013)

Pembangunan akan lebih berhasil jika ditunjang oleh wirausahawan yang dapat membuka lapangan kerja baru. Akan tetapi, minat berwirausaha yang dimiliki oleh kalangan mahasiswa untuk saat ini sangatlah kurang. Pola pikir yang sudah terukir sejak dulu di kalangan masyarakat adalah bekerja di instansi pemerintahan dengan pekerjaan yang mudah dan mendapat gaji tetap, status sosial serta jaminan hidup. Pola pikir seperti inilah yang menyebabkan begitu rendahnya minat berwirausaha di kalangan masyarakat. Untuk itu perlu diciptakan suatu iklim yang dapat mengubah pola pikir tersebut, dengan merubah pola pikir masyarakat khususnya lulusan sarjana dari mencari kerja menjadi menciptakan lapangan kerja. Salah satu cara yang dapat dilakukan adalah dengan menerapkan mata kuliah kewirausahaan seperti yang sekarang ini sedang digalakan di perguruan tinggi. Hampir semua fakultas di Universitas Tadulako Palu sudah menerapkan hal ini yaitu adanya mata kuliah kewirausahaan. Di Fakultas Ekonomi Program Studi Manajemen mata kuliah ini dapat ditempuh mahasiswa pada semester IV dengan jumlah 3 SKS.

Kecerdasan Emosional adalah salah satu faktor yang mempengaruhi minat berwirausaha. Echdar (2013:257) menyatakan "wirausaha yang memiliki kecerdasan emosional yang optimal memiliki peluang lebih untuk mencapai puncak keberhasilan dan menganggap krisis sebagai peluang". Sehingga dapat dikatakan bahwa semakin optimalnya kecerdasan emosional yang dimiliki seseorang wirausaha akan memberikan peluang lebih untuk mencapai puncak keberhasilan.

Karakteristik individu juga termasuk faktor yang mempengaruhi minat berwirausaha. Menurut Ivancevich et. al. (2006:81), karakteristik individu merupakan orang yang memandang berbagai hal secara berbeda dan akan berperilaku secara berbeda pula, orang yang memiliki sikap berbeda akan memberikan respon yang berbeda terhadap perintah, orang yang memiliki kepribadian yang berbeda berinteraksi dengan cara yang berbeda dengan atasan, rekan kerja dan bawahan. Karena karakteristik individu ini dapat menjadi tolok ukur seseorang ketika melakukan sesuatu dalam mengambil keputusan.

Perguruan tinggi idealnya dapat membantu pembentukan minat mahasiswa berwirausaha. Menurut Mahardiana dkk. (2016), disain kurikulum dan metode pengajaran sangat penting agar perkuliahan kewirausahaan dapat meningkatkan sikap positif terhadap kewirausahaan dan meningkatkan minat mahasiswa untuk menjadi wirausahawan. Menurut Eels (1984) dan Mas'oed (1994) dalam Lupiyoadi (2007:39) menyatakan bahwa; "dibandingkan dengan tenaga lain tenaga terdidik S1 memiliki potensi lebih besar untuk berhasil menjadi seorang wirausaha karena memiliki kemampuan penalaran yang telah berkembang dan wawasan berfikir yang lebih luas". Adapun wawasan dalam berwirausaha bagi mahasiswa telah diajarkan dalam mata kuliah kewirausahaan.

Berdasarkan pemikiran tersebut, penulis tertarik untuk meneliti bagaimana pengaruh kecerdasan emosional dan karakteristik individu terhadap minat berwirausaha. Oleh karena itu peneliti mangambil judul "Pengaruh Kecerdasan Emosioal dan Karakteristik Individu Terhadap Minat Berwirausaha Mahasiswa Program Studi Manajemen Fakultas Ekonomi Universitas Tadulako Angkatan 2012, 2013 dan 2014”.

\section{Permasalahan Penelitian} berikut:

Berdasarkan latar belakang yang telah diuraikan maka rumusan masalah adalah sebagai 
1. Apakah kecerdasan emosional dan karakteristik individu secara bersama-sama berpengaruh signifikan terhadap minat berwirausaha mahasiswa Manajemen Fakultas Ekonomi Universitas Tadulako angkatan 2012, 2013 dan 2014?

2. Apakah kecerdasan emosional berpengaruh terhadap minat berwirausaha mahasiswa Manajemen Fakultas Ekonomi Universitas Tadulako angkatan 2012, 2013 dan 2014?

3. Apakah karakteristik individu berpengaruh terhadap minat berwirausaha mahasiswa Manajemen Fakultas Ekonomi Universitas Tadulako angkatan 2012, 2013 dan 2014?

\section{Tujuan Penelitian}

Tujuan yang hendak dicapai dalam penelitian ini sebagai berikut :

1. Untuk mengetahui dan menganalisis kecerdasan emosional dan karakteristik individu secara bersama-sama berpengaruh signifikan terhadap minat berwirausaha mahasiswa Manajemen Fakultas Ekonomi Universitas Tadulako angkatan 2012, 2013 dan 2014.

2. Untuk mengetahui dan menganalisis kecerdasan emosional berpengaruh signifikan terhadap minat berwirausaha mahasiswa Manajemen Fakultas Ekonomi Universitas Tadulako angkatan 2012, 2013 dan 2014.

3. Untuk mengetahui dan menganalisis karakteristik individu berpengaruh signifikan terhadap minat berwirausaha mahasiswa Manajemen Fakultas Ekonomi Universitas Tadulako angkatan 2012, 2013 dan 2014.

\section{KAJIAN LITERATUR DAN PENGEMBANGAN HIPOTESIS Pengertian Kecerdasan Emosional}

Goleman (2003) menyatakan kecerdasan emosi merupakan kemampuan untuk memotivasi diri sendiri dan bertahan menghadapi frustasi mengendalikan dorongan hati dan tidak melebih-lebihkan kesenangan, mengatur suasana hati dan menjaga agar bebas stres, tidak melumpuhkan kemampuan berpikir, berempati dan berdoa. Sehingga dapat dikatakan kecerdasan emosi mempunyai peranan penting dalam meraih kesuksesan pribadi dan professional. Menurut Goleman menyimpulkan kecerdasan emosional merupakan jembatan antara apa yang kita ketahui, dan apa yang akan kita lakukan. Semakin cerdas emosi seseorang ia akan terampil melakukan apapun yang ia ketahui benar.

Salovey dan Mayer (1990) mendefinisikan kecerdasan emosional sebagai kemampuan untuk mengenali perasaan, meraih dan membangkitkan perasaan untuk membantu pikiran, memahami perasaan dan maknanya, dan mengendalikan perasaan secara mendalam sehingga dapat membantu perkembangan emosi dan intelektual. Cooper dan Sawaf (2000) mendefinisikan kecerdasan emosional sebagai kemampuan merasakan, memahami, dan secara efektif menerapkan daya dan kepekaan emosi sebagai sumber energi, informasi, koneksi dan pengaruh yang manusiawi. Lebih lanjut dijelaskan, bahwa kecerdasan emosi menuntut seseorang untuk belajar mengakui, menghargai perasaan diri sendiri dan orang lain serta menanggapinya dengan tepat dan menerapkan secara efektif energi emosi dalam kehidupan sehari-hari.

Mengacu kepada definisi-definisi kecerdasan emosional di atas, maka dapat disimpulakan bahwa kecerdasan emosional itu antara lain adalah jenis kecerdasan yang fokusnya memahami, mengenali, merasakan, mengelola dan memimpin perasaan diri sendiri dan orang lain serta mengaplikasikannya dalam kehidupan pribadi dan sosial; kecerdasan dalam memahami, mengenali, meningkatkan, mengelola dan memimpin motivasi diri sendiri dan orang lain untuk mengoptimalkan fungsi energi, informasi, hubungan dan pengaruh bagi pencapaian-pencapaian tujuan yang dikehendaki dan ditetapkan.

Menurut Goleman (2003) terdapat lima dimensi atau komponen kecerdasan emosional yaitu:

1. Mengenali Emosi Diri

Mengenali emosi diri sendiri merupakan suatu kemampuan untuk mengenali perasaan sewaktu perasaan itu terjadi. Kemampuan ini merupakan dasar dari kecerdasan emosional, para ahli psikologi menyebutkan kesadaran diri sebagai metamood, yakni kesadaran seseorang akan emosinya sendiri. 
Hasby, M.

2. Mengelola Emosi

Mengelola emosi merupakan kemampuan individu dalam menangani perasaan agar dapat terungkap dengan tepat atau selaras, sehingga tercapai keseimbangan dalam diri individu. Menjaga agar emosi yang merisaukan tetap terkendali merupakan kunci menuju kesejahteraan emosi. Emosi berlebihan, yang meningkat dengan intensitas terlampau lama akan mengoyak kestabilan kita (Goleman, 2002).

3. Memotivasi Diri Sendiri

Goleman (2003) menyatakan bahwa motivasi adalah kecenderungan emosi yang mengantar atau memudahkan peralihan sasaran. Penataan emosi sebagai alat untuk mencapai tujuan adalah hal yang sangat penting dalam kaitan untuk memberi perhatian, untuk memotivasi diri sendiri, dan menguasai diri sendiri, dan untuk berkreasi.

4. Mengenali Emosi Orang Lain

Kemampuan untuk mengenali emosi orang lain disebut juga empati. Menurut Goleman (2002) kemampuan seseorang untuk mengenali orang lain atau peduli, menunjukkan kemampuan empati seseorang. Individu yang memiliki kemampuan empati lebih mampu menangkap sinyal-sinyal sosial yang tersembunyi yang mengisyaratkan apa-apa yang dibutuhkan orang lain sehingga ia lebih mampu menerima sudut pandang orang lain, peka terhadap perasaan orang lain dan lebih mampu untuk mendengarkan orang lain.

5. Membina Hubungan

Kemampuan dalam membina hubungan merupakan suatu keterampilan yang menunjang popularitas, kepemimpinan dan keberhasilan antar pribadi (Goleman, 2002). Keterampilan dalam berkomunikasi merupakan kemampuan dasar dalam keberhasilan membina hubungan. Individu sulit untuk mendapatkan apa yang diinginkannya dan sulit juga memahami keinginan serta kemauan orang lain.

\section{Karakteristik Individu}

Menurut Ivancevich et. al. (2006:81) karakteristik individu merupakan orang yang memandang berbagai hal secara berbeda dan akan berperilaku secara berbeda pula, orang yang memiliki sikap berbeda akan memberikan respon yang berbeda terhadap perintah, orang yang memiliki kepribadian yang berbeda berinteraksi dengan cara yang berbeda dengan atasan, rekan kerja dan bawahan. Karena karakteristik individu ini dapat menjadi tolak ukur seseorang ketika melakukan sesuatu dalam mengambil keputusan.

Rivai (2006:147) menyatakan bahwa "Karakteristik individu adalah ciri-ciri khusus, sifat-sifat kejiwaan, akhlak atau budi pekerti yang dimiliki seseorang yang membedakannya dengan orang lain". Menurut Hasibuan (2009:55) "karakteristik individu merupakan sifat pembawaan seseorang yang dapat diubah dengan lingkungan atau pendidikan". Menurut Robbins (2008:56), bahwa variabel ditingkat individu meliputi karakteristik biografis, kemampuan, kepribadian, dan proses belajar.

Selain itu, menurut Gibson, James L yang dialih bahasakan oleh Nunuk Ardiani (1996:123) bahwa yang dimaksud dengan karakteristik individu adalah kemampuan dan kecakapan, latar belakang dan demografi. Klasifikasi dari demografi adalah jenis kelamin dan ras. Perilaku pekerja menentukan hasil. Mereka dapat menghasilkan prestasi jangka panjang yang positif dan pertumbuhan diri atau sebaliknya, prestasi jangka panjang yang jelek atau kurang berkembang.

Meredith (1996:5-6) dalam Mudjiarto (2006:5) mengemukakan 6 karakteristik individu yang lebih mengarah ke ciri-ciri dan watak kewirausahaan, yaitu:

1. Percaya Diri

Percaya diri adalah suatu keyakinan seseorang terhadap segala aspek kelebihan yang dimiliki seseorang dan keyakinan tersebut membuatnya merasa mampu untuk bisa mencapai tujuan dalam hidupnya. (Hakim, 2004:6)

2. Berorientasi pada Tugas dan Hasil

Seseorang yang selalu mengutamakan tugas dan hasil adalah orang yang selalu mengutamakan nilai-nilai motif prestasi, berorientasi pada laba, ketekunan dan ketabahan, tekad kerja keras, mempunyai dorongan kuat, enerjik dan berinisiatif. (Meredith, 1996)

3. Pengambilan Risiko 
Keberanian dalam mengambil risiko adalah kemampuan dalam mengambil risiko dan suka pada tantangan. Untuk mencapai kesuksesan dan menghadapi kegagalan, seorang wirausaha harus berani mengambil risiko dan menghadapi segala tantangan. (Meredith, 1996)

4. Kepemimpinan

Menurut SP. Siagian (2002:235) kepemimpinan adalah kemampuan seseorang untuk mempengaruhi orang lain dalam hal bawahannya, sedemikian rupa sehingga orang lain itu mau melakukan kehendak pimpinan, meskipun secara pribadi hal itu mungkin tidak disenanginya.

5. Keorisinilan

Keorisinilan terdiri dari kreativitas dan keinofasian. Kreativitas adalah kemampuan untuk berpikir yang baru dan berbeda sedangkan keinofasian adalah kemampuan untuk bertindak yang baru dan berbeda.

6. Berorientasi Masa Depan

Menurut Meredith (1996) Berorientasi ke masa depan terdiri dari pandangan ke depan dan perseptif. Pandangan ke depan adalah pandangan jauh kedepan selalu mencari peluang, tidak cepat puas dengan keberhasilan yang telah dicapai. Sedangkan perseptif adalah seseorang yang mempunyai kesadaran yang tajam, cepat mengerti dan cerdik.

\section{Pengertian Minat}

Minat adalah suatu rasa lebih suka dan rasa ketertarikan pada suatu hal atau aktivitas tanpa ada yang menyuruh. Minat pada dasarnya merupakan penerimaan akan suatu hubungan antara diri sendiri dengan sesuatu di luar diri semakin kuat atau dekat hubungan tersebut semakin besar minat (Slameto, 2010: 180). Minat adalah seperangkat mental yang terdiri dari suatu campuran perasaan, harapan, pendirian, prasangka rasa takut atau kecenderungan-kecenderungan lain yang mengarahkan individu kepada suatu pilihan tertentu (Mapiere, 1982:60)

Melihat pendapat di atas dapat disimpulkan bahwa minat merupakan kesadaran seseorang yang dapat menimbulkan adanya keinginan suatu hal daripada hal lainnya dengan aktif melakukan kegiatan yang menjadi objek kesukaannya. Keinginan yang timbul dalam diri individu tersebut dinyatakan dengan suka atau tidak suka, terhadap suatu keinginan yang akan memuaskan kebutuhan.

\section{Pengertian Berwirausaha}

Konsep kewirausahaan sampai saat ini masih berkembang dan terus-menerus dikembangkan. Kewirausahaan muncul apabila seseorang individu berani mengembangkan usaha-usaha dan ide-ide barunya. Tidak sedikit pengertian mengenai kewirausahaan yang saat ini muncul seiring dengan perkembangan ekonomi dengan semakin meluasnya bidang dan garapan. Meredith $(2005 ; 14)$ menyatakan bahwa wirausaha adalah orang-orang yang mempunyai kemampuan melihat dan menilai kesempatan usahan mengumpulkan serta sumber daya yang dibutuhkan guna mengambil keuntungan daripadanya dan mengambil tindakan yang tepat guna memastikan kesuksesan.

Totok S. Wiryasaputra (2004; 16), wirausaha adalah orang yang ingin bebas, merdeka, mengatur kehidupannya sendiri, dan tidak bergantung pada belas kasihan orang lain. Mereka ingin menghasilkan uang sendiri. Uang didapatkan dari kekuatan dan usahanya sendiri. Mereka harus menciptakan sesuatu yang benar-benar baru atau memberi nilai tambah pada sesuatu yang mempunyai nilai untuk dijual atau layak dibeli sehingga menghasilkan uang bagi dirinya sendiri dan bahkan bagi orang yang di sekelilingnya.

\section{Pengertian Minat Berwirausaha}

Melihat pengertian minat dan wirausaha yang telah diungkap diatas, maka dapat diberikan pengertian dari minat berwirausaha. Minat berwirausaha adalah kombinasi dari perhatian, keinginan, perasaan senang, ketertarikan, harapan dan kemauan atau kecenderungan-kecenderungan untuk berbuat atau beraktivitas yang mengarahkan kepada suatu pilihan bidang kerja wirausaha. Sedang bidang kerja yang dimaksud adalah jenis pekerjaan atau usaha yang diciptakan sendiri dengan mengarahkan seluruh kemampuan yang dimilikinya yang disertai dengan sikap mental yang penuh keberanian, kesadaran dan tanggung jawab pada diri sendiri.

Minat berwirausaha yaitu rasa tertariknya seseorang untuk melakukan kegiatan usaha yang mandiri dengan keberanian mengambil risiko. Minat tinggi berarti kesadaran bahwa wirausaha 
melekat pada dirinya sehingga individu lebih banyak perhatian dan lebih senang melakukan kegiatan wirausaha (Susatyo, 2008:3).

Minat berwirausaha merupakan pemusatan perhatian pada wirausaha karena adanya rasa suka dan disertai keinginan mempelajari, mengetahui dan membuktikan lebih lanjut terhadap wirausaha. Minat berwirausaha muncul karena adanya pengetahuan dan informasi mengenai kewirausahaan yang kemudian dilanjutkan untuk berpartisipasi secara langsung dalam rangka mencari pengalaman dan akhirnya timbul keinginan untuk memperhatikan pengalaman yang telah didapatkan tersebut. Serta mempunyai perasaan senang dan mempunyai keinginan untuk terlibat dalam kegiatan pengambilan risiko, untuk menjalankan bisnis atau usaha sendiri dengan memanfaatkan peluang-peluang bisnis yang ada, dan menciptakan bisnis baru dengan pendekatan inovatif.

\section{Faktor-faktor yang Mempengaruhi Minat Berwirausaha}

Menurut Winkel (2004: 650) minat yaitu kecenderungan yang menetap pada seseorang untuk merasa tertarik pada suatu bidang tertentu dan merasa senang dalam berbagai kegiatan yang berkaitan dengan bidang itu sendiri. Pada dasarnya minat menurut Winkel (2004) dibagi menjadi 4 unsur yakni:

1. Perasaan Senang

Perasaan adalah suatu keadaan kerohanian atau peristiwa kejiwaan yang kita alami dengan senang atau tidak senang dalam hubungan dengan peristiwa mengenal dan bersifat subyektif (Ahmadi, 2009:101).

2. Perhatian

Perhatian merupakan pemusatan atau konsentrasi dari seluruh aktivitas individu yang ditujukan kepada sesuatu atau kelompok obyek (Walgito, 2002:78). Perhatian akan menimbulkan minat seseorang jika subyek mengalami keterlibatan dalam obyek.

3. Kesadaran

Timbulnya minat dari diri seseorang dapat pula diawali dari adanya kesadaran bahwa suatu objek itu mempunyai manfaat bagi dirinya. Kesadaran itu mutlak harus ada dan dengan kesadaran itu pula seseorang akan mengenai objek yang dirasa ada daya tarik bagianya. (Winkel, 2004)

1. Kemauan

Seseorang dapat dikatakan mempunyai minat terhadap sesuatu apabila seseorang mempunyai kecenderungan untuk mencapai tujuan yang diinginkan atau mempunyai kemauan untuk mewujudkan tujuan-tujuan yang dikehendaki. Dengan demikan kemauan tersebut akan mendorong kehendak yang dikenalkan oleh pikiran dan terarah pada suatu tujuan. (Winkel, 2004).

\section{Hubungan Kecerdasan Emosional dengan Minat Berwirausaha}

Menurut Salovey dan Mayer, kecerdasan emosional adalah kemampuan untuk mengenali perasaan, meraih dan membangkitkan perasaan untuk membantu pikiran, memahami perasaan dan maknanya, dan mengendalikan perasaan secara mendalam sehingga membantu perkembangan emosi dan intelektual (dalam Rissyo dan Aziza, 2006). Sedangkan pengertian minat berwirausaha adalah berkemauan dan berkemampuan melihat kesempatan-kesempatan usaha untuk mengambil keuntungan darinya dengan mengambil tindakan yang tepat.

Penelitian yang dilakukan oleh Helmi dan Ifham (2002) mengenai hubungan kecerdasan emosional dan kewirausahaan, ditemukan suatu hubungan positif antara kecerdasan emosional dan kewirausahaan. Karena dalam kewirausahaan membutuhkan suatu kecerdasan dalam pencarian informasi guna mengidentifikasi peluang-peluang yang ada dan kemampuan untuk berbenah diri dalam penanggungan risiko. Hal tersebut dapat dilakukan oleh seseorang dengan perkembangan emosi dan intelektual yang baik. Karena itu diperlukan kecerdasan emosi yang dapat mendukung pemikiranpemikiran dan kemampuan intelektual seseorang yang mengarah pada kewirausahaan.

Berdasarkan penelitian tersebut, penulis akan meneliti lebih lanjut untuk menguji pengaruh antara kecerdasan emosional terhadap minat berwirausaha pada mahasiswa Manajemen Fakultas Ekonomi Universitas Tadulako.

\section{Hubungan Karakteristik Individu dengan Minat Berwirausaha}

Menurut Ivancevich et al (2006:81) karakteristik individu merupakan orang yang memandang berbagai hal secara berbeda dan akan berperilaku secara berbeda pula, orang yang memiliki sikap 
berbeda akan memberikan respon yang berbeda terhadap perintah, orang yang memiliki kepribadian yang berbeda berinteraksi dengan cara yang berbeda dengan atasan, rekan kerja dan bawahan.

Drucker (1994), menyatakan bahwa membuat seseorang menjadi wirausaha adalah karakteristik spesifik yang dimiliki selain ukuran pertumbuhan perusahaan. Seorang wiraswastawan adalah orang-orang yang mempunyai kemampuan melihat dan menilai kemampuan bisnis, mengumpulkan sumber daya yang dibutuhkan guna mengambil keuntungan dan mengambil tindakan yang tepat.

Sejumlah faktor diduga berpengaruh terhadap minat berwirausaha mahasiswa, misalnya karakteristik individu, seperti; kemampuan, kepribadian, persepsi dan sikap. Penelitian yang dilakukan oleh Pambudi Rahardjo (2010), mengenai hubungan karakteristik individu dengan keputusan menjadi wirausaha baru sebagai alternatif karir lulusan perguruan tinggi menemukan bahwa faktor karakteristik individu berperan penting terhadap keputusan lulusan perguruan tinggi untuk berwirausaha. Pandangan bahwa berwirausaha merupakan hal yang dinamis dan menantang dan dapat menjadi bos usaha sendiri turut mendasari pengambilan keputusan seseorang untuk berwirausaha.

Berdasarkan penelitian tersebut, penulis akan meneliti lebih lanjut untuk menguji pengaruh antara karakteristik individu terhadap minat berwirausaha pada mahasiswa Manajemen Fakultas Ekonomi Universitas Tadulako.

\section{Kerangka Pemikiran}

Minat Berwirausaha dipengaruhi oleh beberapa faktor, dalam penelitian ini akan diukur adalah pengaruh Kecerdasan Emosional dan Karakteristik Individu terhadap Minat Berwirausaha mahasiswa Manajemen Fakultas Ekonomi Universitas Tadulako angkatan 2012, 2013 dan 2014.

Berdasarkan latar belakang dan rumusan masalah yang telah diuraikan pada bab sebelumnya, maka dapat dijelaskan konseptual dari penelitian ini, variabel independen pada penelitian ini yaitu Kecerdasan Emosional (X1) yang diukur dari beberapa aspek, yakni; mengenali emosi diri, mengelola emosi, memotivasi diri sendiri, mengenali emosi orang lain, dan membina hubungan. Kemudian Karakteristik Individu (X2) diukur dari aspek; percaya diri, berorientasi tugas dan hasil, keberanian mengambil risiko, kepemimpinan, keorisinilan dan berorientasi masa depan. Sedangkan variabel dependen pada penelitian ini yaitu Minat Berwirausaha (Y) yang meliputi; perasaan senang, perhatian, kesadaran dan kemauan.

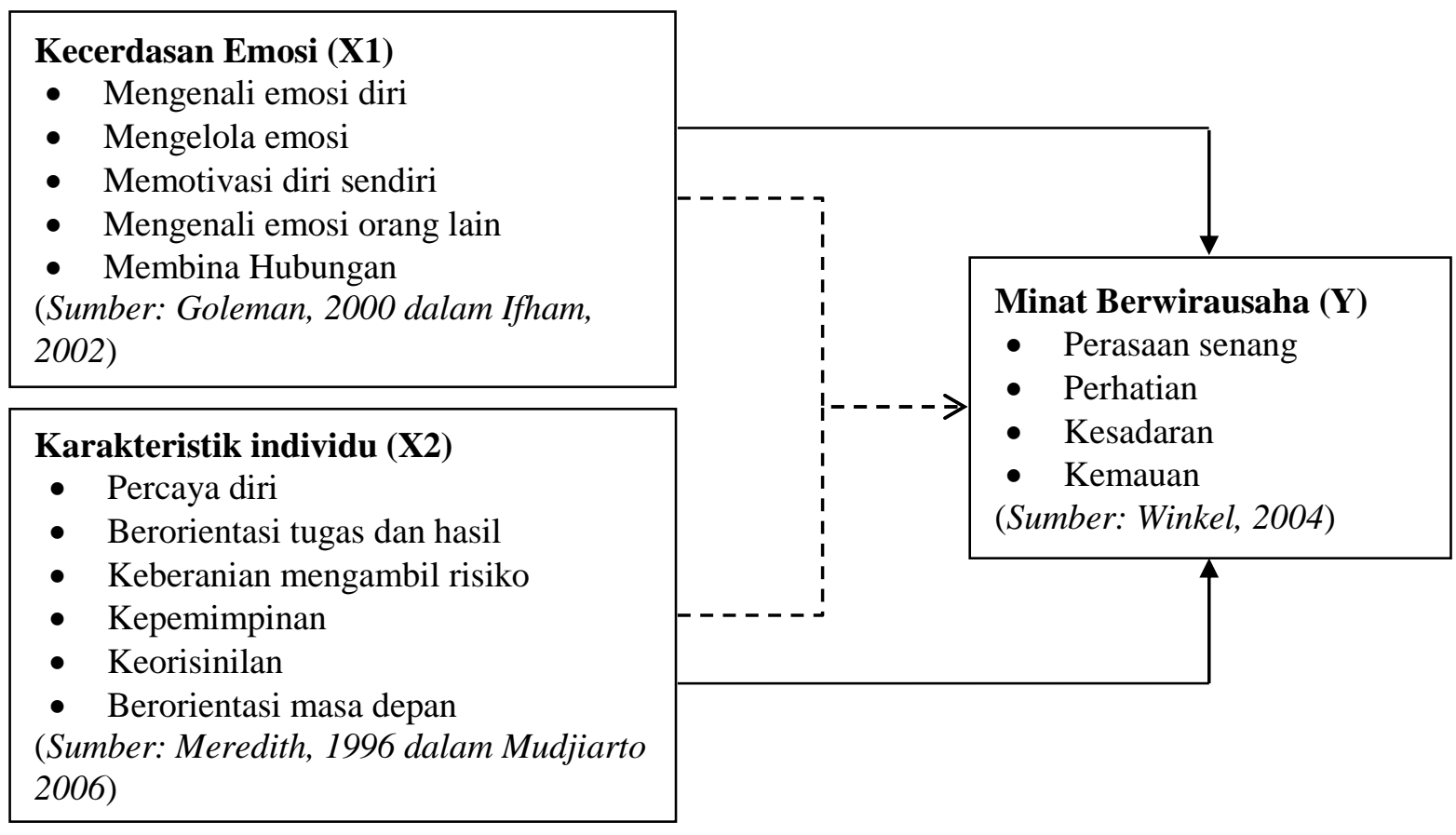

Gambar 1. Kerangka Pemikiran 
Hasby, M.

\section{Hipotesis}

Beranjak dari permasalahan-permasalahan pokok di atas, maka yang menjadi hipotesis penelitian ini adalah sebagai berikut:

1. Kecerdasan Emosional dan Karakteristik Individu secara bersama-sama berpengaruh positif dan signifikan terhadap Minat Berwirausaha mahasiswa Manajemen Fakultas Ekonomi Universitas Tadulako angkatan 2012, 2013 dan 2014.

2. Kecerdasan Emosional berpengaruh positif dan signifikan terhadap Minat Berwirausaha mahasiswa Manajemen Fakultas Ekonomi Universitas Tadulako angkatan 2012, 2013 dan 2014.

Karakteristik Individu berpengaruh positif dan signifikan terhadap Minat Berwirausaha mahasiswa Manajemen Fakultas Ekonomi Universitas Tadulako angkatan 2012, 2013 dan 2014.

\section{METODE PENELITIAN}

\section{Populasi dan Teknik Penarikan Sampel \\ Populasi}

Populasi adalah wilayah generalisasi yang terdiri atas: obyek/subyek yang mempunyai kualitas dan karakteristik tertentu yang ditetapkan oleh peneliti untuk dipelajari dan kemudian ditarik kesimpulan, Sugiyono (2013:115). Populasi dalam penelitian ini adalah seluruh mahasiswa Program Studi Manajemen Fakultas Ekonomi Universitas Tadulako yang masih aktif mengikuti perkuliahan di kelas yaitu angkatan 2012, 2013 dan 2014.

Tabel 1. Banyaknya Mahasiswa Program Studi Manajemen Fakultas Ekonomi Universitas Tadulako angkatan 2012, 2013 dan 2014

\begin{tabular}{cc}
\hline Angkatan & Jumlah Mahasiswa \\
\hline $\mathbf{2 0 1 2}$ & 235 \\
$\mathbf{2 0 1 3}$ & 214 \\
$\mathbf{2 0 1 4}$ & 280 \\
\hline Jumlah & $\mathbf{7 2 9}$ \\
\hline
\end{tabular}

Sumber: Data primer yang diolah, 2016

Berdasarkan Tabel 1 yang menjadi populasi pada penelitian ini adalah 729 mahasiswa angkatan 2012, 2013 dan 2014 yang telah lulus dalam mata kuliah kewirausahaan.

\section{Teknik Pengumpulan dan Penarikan Sampel}

Menurut Sugiyono (2013:116) sampel adalah bagian dari jumlah dan karakteristik yang dimiliki oleh populasi tersebut. Sedangkan menurut Arikunto (2010:174) sampel adalah sebagian atau wakil populasi yang diteliti.

Pengambilan sampel dalam penelitian ini menggunakan teknik Purposive Sampling. Menurut Masri Singarimbun (1989:169) "Purposive Sampling merupakan teknik yang memilih sampel berdasarkan pertimbangan-pertimbangan tertentu berdasarkan tujuan penelitian". Adapun pertimbangan-pertimbangan dari mahasiswa yang dijadikan sampel adalah:

a. Mahasiswa yang sudah lulus mata kuliah kewirausahaan.

Mata kuliah kewirausahaan memberikan wawasan kepada mahasiswa tentang apa itu kewirausahaan sehingga mahasiswa yang sudah mengikuti mata kuliah kewirausahaan lebih mudah dalam memahami pertanyaan atau pernyataan yang diajukan dalam penelitian ini.

b. Mahasiswa belum lulus ujian pendadaran.

Mahasiswa yang belum lulus ujian pendadaran artinya mahasiswa yang masih aktif mengikuti perkuliahan di kampus.

c. Mahasiswa tidak dalam keadaan cuti.

Mahasiswa yang dalam keadaan cuti adalah mahasiswa yang tidak mengikuti kegiatan akademik dalam jangka waktu tertentu sehingga cuti kuliah tidak diperhitungkan sebagai masa studi.

Untuk mendapatkan data yang valid maka penulis menentukan jumlah sampel-sampel berdasarkan rumus Slovin yaitu sebagai berikut: 


$$
n=\frac{\mathrm{N}}{1+N e^{2}}
$$

Keterangan:

$\mathrm{n}=$ jumlah sampel yang diperlukan

$\mathrm{N}=$ jumlah anggota populasi

$\mathrm{e}=$ persen kesalahan yang diinginkan/ditolerir (sebesar 10\%), dasarnya adalah kesalahan yang dapat ditolerir sebesar 10\% dengan tingkat kepercayaan 90\% (Sugiyono, 2004). Alasan digunakannya eror $10 \%$ adalah mengacu pada tingkat kesalahan maksimal yang dapat ditolerir pada penelitian ilmu social (Sugiyono, 2004).

Dalam penelitian ini, jumlah populasi 729 dimasukkan kedalam rumus tersebut dan menghasilkan nilai 88 (pembulatan) sampel tersebut seperti tampak sebagai berikut:

$$
\begin{aligned}
& \mathrm{n}=\frac{729}{1+729(0.1)^{2}} \\
& \mathrm{n}=87,93 \text { dibulatkan menjadi } 88 \text { orang }
\end{aligned}
$$

Maka perbandingan untuk masing-masing angkatan adalah sebagai berikut:

Angkatan 2012: $235 / 729=0.3223 \times 88$ orang $=28$ orang

Angkatan 2013: $214 / 729=0.2935 \times 88$ orang $=26$ orang

Angkatan 2014: $280 / 729=0.3840$ x 88 orang $=34$ orang

\begin{tabular}{|c|c|c|c|c|c|}
\hline \multirow[t]{2}{*}{ Variabel } & \multicolumn{2}{|c|}{$\begin{array}{l}\text { Unstandardized } \\
\text { Coefficients (B) }\end{array}$} & $\begin{array}{c}\text { Standardized } \\
\text { Coefficients }\end{array}$ & \multirow[t]{2}{*}{$\mathrm{t}$} & \multirow[t]{2}{*}{ Sig. } \\
\hline & B & Std. Error & Beta & & \\
\hline$($ Constant $)$ & .853 & .314 & & 2.719 & .008 \\
\hline Periklanan $\left(\mathrm{X}_{1}\right)$ & .252 & .073 & .300 & 3.460 & .001 \\
\hline Promosi Penjualan $\left(\mathrm{X}_{2}\right)$ & .528 & .085 & .535 & 6.179 & .000 \\
\hline $\mathrm{R}$ Square $\left(\mathrm{R}^{2}\right)$ & $=0.551$ & F- hitung & $=52.202$ & & \\
\hline Adjusted R Square & $=0.441$ & Constanta & $=0.857$ & & \\
\hline Multiple R & $=0.742$ & Sig. F & $=0.000$ & & \\
\hline
\end{tabular}

\section{HASIL DAN PEMBAHASAN}

Tabel 2. Hasil Perhitungan Regresi Linear Berganda

Sumber: Output For Windows Release 16.0, 2015

Berdasarkan uraian Tabel 2. tentang hasil perhitungan regresi linear berganda, maka persamaan regresi yang dibangun dengan menggunakan nilai-nilai yang diperlukan sebagai berikut:

$$
\mathrm{Y}=0,853+0,252\left(\mathrm{X}_{1}\right)+0,528\left(\mathrm{X}_{2}\right)
$$

\section{Pengujian Hipotesis}

Pengujian Hipotesis Pertama Secara Simultan (Serempak/Uji F)

Berdasarkan hasil uji regresi pada tabel di atas, diperoleh $\mathrm{F}_{\text {hitung }}$ sebesar 52.202 dengan tingkat signifikansi $0,000<0,05$, yang dapat diartikan bahwa variabel Kecerdasan Emosional (X1) dan variabel Karakteristik Individu (X2) yang dimasukkan dalam model, secara serempak berpengaruh signifikan terhadap variabel Minat Berwirausaha (Y). berdasarkan hasil tersebut dapat disimpulkan bahwa $\mathrm{H}_{0}$ ditolak dan $\mathrm{H}_{\mathrm{a}}$ diterima, atau bila dijabarkan secara mendasar bahwa dalam penelitian ini hipotesis yang pertama terbukti sebagai suatu kebenaran empiris (nyata) setelah diuji dengan hasil penelitian. 


\section{Pengujian Hipotesis Kedua dan Ketiga (Uji Parsial/Uji t)}

Pengujian terhadap pengaruh masing-masing variabel independen terhadap variabel dependen disebut uji parsial. Uji parsial pada fungsi estimasi bertujuan untuk membuat kesimpulan mengenai pengaruh masing-masing variabel independen $(\mathrm{X})$ terhadap variabel dependen $(\mathrm{Y})$. Uji t dilakukan dengan membandingkan nilai $\mathrm{t}$ sig. dengan nilai $\alpha$. Jika probabilitas $\mathrm{t}$ sig. $<\alpha(0,05)$ maka tidak terdapat pengaruh signifikan, sebaliknya jika nilai t sig. $>\alpha(0,05)$ maka tidak terdapat pengaruh signifikan. Berdasarkan hasil pengujian yang diperoleh dalam penelitian, dapat dijelaskan hasil uji $\mathrm{t}$ dari variabel independen adalah sebagai berikut:

a. Kecerdasan Emosional (X1)

Variabel kecerdasan emosional memiliki tingkat signifikansi t sig. $(0,001)<\alpha(0,05)$. Hal ini menunjukkan bahwa hipotesis yang menyatakan "Kecerdasan emosional secara parsial berpengaruh signifikan terhadap minat berwirausaha mahasiswa Manajemen Fakultas Ekonomi Universitas Tadulako" terbukti atau hipotesis tersebut diterima.

b. Karakteristik Individu (X2)

Variabel karakteristik individu memiliki tinngkat signifikansi probabilitas $\mathrm{t}$ sig. $(0.000)<\alpha$ $(0,05)$. Hal ini menunjukkan bahwa hipotesis yang menyatakan bahwa "Karakteristik individu berpengaruh signifikan terhadap minat berwirausaha mahasiswa Manajemen Fakultas Ekonomi Universitas Tadulako" terbukti atau hipotesis tersebut diterima

\section{Pembahasan Hasil Penelitian}

\section{Pengaruh Kecerdasan Emosional dan Karakteristik Individu Terhadap Minat Berwirausaha Mahasiswa Manajemen Fakultas Ekonomi Universitas Tadulako}

Variabel kecerdasan emosional dan karakteristik individu pada mahasiswa Manajemen Fakultas Ekonomi Universitas Tadulako memiliki peranan yang signifikan terhadap minat berwirausaha. Hal ini dapat dilihat bahwa kecerdasan emosional dan karakteristik individu pada mahasiswa Manajemen Fakultas ekonomi Universitas Tadulako merupakan variabel yang mempengaruhi minat berwirausaha disamping variabel lainnya yang tidak dibahas dalam penelitian ini. Sumbangan pengaruh kecerdasan emosional dan karakteristik individu terhadap minat berwirausaha mahasiswa sebesar $55,1 \%$. Hal ini berarti masih ada $44,9 \%$ faktor-faktor lainnya yang mempengaruhi minat berwirausaha mahasiswa Manajemen Fakultas Ekonomi Universitas Tadulako yang tidak dibahas pada penelitian ini. Berdasarkan Tabel 5.15 diketahui besarnya $F_{\text {hitung }} 52,202$ pada signifikan probabilitas 0,000 , menunjukkan bahwa terdapat pengaruh yang positif dan signifikan dari variabel kecerdasan emosional dan karakteristik individu terhadap minat berwirausaha mahasiswa Manajemen Fakultas Ekonomi Universitas Tadulako.

Emosi pada dasarnya merupakan sebuah dorongan untuk melakukan sesuatu, dimana dibutuhkan sebuah keterampilan dalam mengelola emosi tersebut. Kecerdasan emosional merupakan sebuah kemampuan dalam mengenal dan mengelola emosi diri maupun orang lain. Kemudian karakteristik individu merupakan ciri-ciri khusus atau sifat-sifat kejiwaan yang dimiliki oleh seseorang yang membedakannya dengan orang lain.

Hasil penelitian ini mengindikasikan bahwa mahasiswa Manajemen Fakultas Ekonomi Universitas Tadulako memiliki kecerdasan emosional yang baik dan karakter dalam hal berwirausaha. Dengan dimilikinya kecerdasan emosional yang baik dan karakter kewirausahaan maka mahasiswa akan mengetahui seluk beluk kewirausahaan. Kondisi dimana mahasiswa mengetahui seluk beluk kewirausahaan, maka ketertarikan terhadap wirausaha akan semakin tinggi dan pada gilirannya akan mempengaruhi minatnya dalam berwirausaha. Hasil penelitian ini mendukung penelitian yang dilakukan oleh Mahardiana dkk. (2016), yang menyatakan bahwa mahasiswa Fakultas Ekonomi Universitas Tadulako setelah mengikuti dan lulus pada mata kuliah kewirausahaan, maka timbul sikap ketertarikan terhadap dunia usaha atau bisnis dan pada gilirannya akan memunculkan minat untuk berwirausaha.

\section{Pengaruh Kecerdasan Emosional Terhadap Minat Berwirausaha Mahasiswa Manajemen Fakultas Ekonomi Universitas Tadulako}

Berdasarkan hasil penelitian koefisien untuk variabel kecerdasan emosional adalah sebesar 0,252 atau $25,2 \%$. Hal ini berarti jika kecerdasan emosional ditingkatkan, maka minat berwirausaha mahasiswa Manajemen Fakultas Ekonomi Universitas Tadulako akan meningkat sebesar 25,2\%. 
Sedangkan uji t menunjukkan bahwa $t_{\text {hitung }}$ yang diperoleh sebesar 3.460 pada tingkat signifikansi 0,001, sehingga dapat disimpulkan bahwa variabel kecerdasan emosional berpengaruh signifikan terhadap minat berwirausaha mahasiswa Manajemen Fakultas Ekonomi Universitas Tadulako. Hal ini juga menunjukkan bahwa hipotesis kedua diterima yakni "kecerdasan emosional berpengaruh signifikan terhadap minat berwirausaha mahasiswa Manajemen Fakultas Ekonomi Universitas Tadulako" terbukti.

Berdasarkan hasil penelitian, maka dapat dijelaskan berdasarkan indikator kecerdasan emosional sebagai berikut:

1. Mengenali emosi diri, merupakan kemampuan untuk mengenali emosi yang ada pada diri sendiri. Mahasiswa yang mengenali emosi diri lebih mengetahui kelebihan dan kelemahan yang dimilikinya, sehingga dengan mengetahui kelebihan yang dimiliki mahasiswa akan berfikir positif dan optimis tentang dirinya sendiri dan dengan mengetahui kelemahan mahasiswa akan terus mengembangkan diri untuk menjadi seorang wirausahawan yang sukses. Sehigga dengan kemampuan mengenali emosi diri ini mahasiswa Manajemen Fakultas ekonomi Untad akan mengetahui kelebihan yang dimilikinya untuk berwirausaha sehingga akan muncul ketertarikan untuk berwirausaha.

2. Mengelola emosi, merupakan penanganan perasaan agar bisa terungkap dengan pas dan tepat tanpa merugikan diri sendiri dan orang lain. Mahasiswa yang dapat mengelola emosinya dapat berfikir lebih sehingga memudahkan dalam hal pengambilan keputusan, salah satunya keputusan menjadi wirausahawan. Mahasiswa Manajemen Fakultas Ekonomi Untad yang dapat mengelola emosinya dan mengetahui bahwa hal tersebut dibutuhkan dalam dunia usaha maka akan menimbulkan minat untuk berwirausaha.

3. Memotivasi diri sendiri, merupakan penataan emosi sebagai alat untuk mencapai tujuan. Mahasiswa yang dapat memotivasi dirinya sendiri cenderung akan selalu optimis dengan tujuan yang dimilikinya. Tujuan yang dimaksud disini adalah minat berwirausaha. Sehingga mahasiswa Manajemen Fakultas Ekonomi Untad yang dapat memotivasi diri sendiri akan lebih optimis untuk menjadi wirausahawan sehingga hal tersebut mempengaruhi minatnya dalam berwirausaha.

4. Mengenali emosi orang lain, merupakan kemampuan untuk memahami perasaan orang lain yang ada disekitar kita. Mahasiswa memiliki kemampuan mengenali emosi orang lain atau empati lebih mampu menangkap sinyal-sinyal sosial yang tersembunyi yang mengisyaratkan apa-apa yang dibutuhkan atau yang diinginkan orang lain. Sehingga hal tersebut sangat penting untuk menjadi wirausahawan yang sukses. Dengan adanya pengetahuan tersebut maka akan berpengaruh terhadap minat berwirausaha kepada mahasiswa Manajemen Fakultas Ekonomi Untad karena dalam dunia usaha dibutuhkan hal tersebut untuk keberhasilan usaha.

5. Membina hubungan, adalah sebuah keterampilan dalam menjalin dan memelihara hubungan baik dengan orang lain. Untuk menjadi wirausahawan yang sukses mahasiswa haruslah memiliki kemampuan berkomunikasi dengan orang lain secara baik bahkan dengan orang yang baru dijumpainya. Mahasiswa Manajemen Fakultas Ekonomi Untad yang memiliki kemampuan tersebut akan mempengaruhi minatnya dalam berwirausaha karena untuk menjadi wirausahawan yang sukses perlu kemampuan membina hubungan.

Hasil penelitian ini sejalan dengan penelitian yang dilakukan oleh Ahmad Ifham dan Avin F. Helmi (2002) yang menyatakan bahwa kecerdasan emosi berkorelasi positif dengan kewirausahaan pada mahasiswa dari berbagai perguruan tinggi di Jogjakarta. Penelitian ini juga sejalan dengan penelitian yang dilakukan oleh Irene Paulina dan Wardoyo (2012) yang menyatakan bahwa kecerdasan emosi berpengaruh langsung dan positif terhadap intensi berwirausaha. Semakin tinggi persepsi mahasiswa terhadap kecerdasan emosi yang dimiliki maka intensi berwirausahanya akan semakin baik.

\section{Pengaruh Karakteristik Individu Terhadap Minat Berwirausaha Mahasiswa Manajemen Fakultas Ekonomi Universitas Tadulako}

Variabel karakteristik individu merupakan variabel yang memberikan kontribusi paling besar dan berpengaruh signifikan terhadap minat berwirausaha mahasiswa Manajemen Fakultas Ekonomi Universitas Tadulako. Berdasarkan hasil pengujian koefisien untuk variabel karakteristik individu adalah sebesar 0,528, hal ini berarti ketika karakteristik individu ditingkatkan maka minat 
berwirausaha mahasiswa akan meningkat sebesar $52,8 \%$. Sedangkan uji t menunjukkan bahwa $t_{\text {hitung }}$ yang diperoleh sebesar 6.179 pada tingkat signifikansi 0,000, sehingga dapat disimpulkan bahwa variabel karakteristik individu berpengaruh signifikan terhadap minat berwirausaha mahasiswa Manajemen Fakultas Ekonomi Universitas Tadulako. Hal ini juga menunjukkan bahwa hipotesis ketiga diterima "Karakteristik individu berpengaruh signifikan terhadap minat berwirausaha mahasiswa Manajemen Fakultas Ekonomi Universitas Tadulako" terbukti.

Berdasarkan hasil penelitian, maka dapat dijelaskan berdasarkan indikator karakteristik individu sebagai berikut:

1. Percaya diri, merupakan suatu keyakinan seseorang terhadap segala aspek kelebihan yang dimiliki. Mahasiswa yang memiliki rasa percaya diri yang tinggi untuk menjadi seorang wirausahawan, mereka memiliki keyakinan bahwa mereka mampu mencapai tujuan tersebut sehingga minat untuk berwirausaha mahasiswa Manajemen Fakultas Ekonomi Untad juga akan semakin tinggi.

2. Berorientasi tugas dan hasil, artinya selalu mengutamakan tugas atau pekerjaan untuk memperoleh hasil yang baik. Mahasiswa yang ingin menjadi seorang wirausahawan perlu memiliki orientasi terhadap tugas dan hasil, sehingga hasil yang dicapai memiliki kualitas atau mutu yang baik. Dengan pengetahuan tersebut bahwa berwirausaha akan berhasil jika berorientasi pada tugas dan hasil maka akan menimbulkan ketertarikan untuk berwirausaha pada mahasiswa Manajemen Fakultas Ekonomi Untad.

3. Pengambilan risiko, merupakan kemampuan dalam mengambil risiko dan suka pada tantangan. Untuk menjadi seorang wirausahawan yang sukses mahasiswa harus memiliki keberanian dalam mengambil risiko, karena dalam dunia kewirausahaan banyak risiko-risiko yang akan dihadapi. Dengan dimilikinya keberanian mengambil risiko ini maka mahasiswa Manajemen Fakultas Ekonomi Untad akan muncul ketertarikan untuk berwirausaha.

4. Kepemimpinan, kemampuan seseorang untuk mempengaruhi orang lain dalam hal bawahannya. Mahasiswa harus memiliki jiwa kepemimpinan untuk menjadi wirausahawan yang sukses, karena menjadi wirausahawan diperlukan kemampuan mempengaruhi orang lain untuk pencapaian tujuan. Dengan dimilikinya jiwa kepemimpinan tersebut dan adanya pengetahuan mahasiswa Manajemen Fakultas Ekonomi Untad bahwa berwirausaha harus berjiwa kepemimpinan maka ketertarikan terhadap wirausaha akan semakin tinggi.

5. Keorisinilan, adalah kemampuan untuk berfikir yang baru dan bertindak yang baru atau berbeda. Mahasiswa harus memiliki kemampuan kreatif dan inovatif karena menjadi wirausahawan akan memiliki banyak pesaing sehingga dibutuhkan keorisinilan untuk membuat hal yang berbeda. Mahasiswa Manajemen Fakultas Ekonomi Untad yang memiliki jiwa keorisinilan maka akan mempengaruhi minatnya untuk berwirausaha karena dalam dunia usaha dibutuhkan keorisinilan.

6. Berorientasi masa depan, merupakan pandangan ke masa depan. Mahasiswa yang ingin menjadi wirausahawan yang sukses perlu memiliki orientasi masa depan, karena memiliki pandangan jauh ke masa depan maka ia akan selalu berusaha untuk berkarya. Mahasiswa Manajemen Fakultas Ekonomi untad yang memiliki orientasi masa depan dan mengetahui bahwa hal tersebut dibutuhkan untuk menjadi wirausahawan yang sukses maka akan menimbulkan ketertarikan untuk berwirausaha.

Hasil penelitian ini sejalan dengan penelitian yang dilakukan oleh Pambudi Rahardjo (2010) yang menyatakan bahwa karakteristik individu terbukti berpengaruh positif terhadap keputusan menjadi wirausaha baru di Purwokerto (Studi tentang alternative karir lulusan PT). Penelitian ini juga sejalan dengan penelitian yang dilakukan oleh Eliana Marizka Hade Putri dan Lieli Suharti (tidak dipublikasikan) yang menyatakan bahwa karakteristik individu terbukti berpengaruh terhadap keputusan menjadi wirausaha bagi lulusan perguruan tinggi.

\section{KESIMPULAN DAN SARAN}

\section{Kesimpulan}

Berdasarkan uraian hasil penelitian dan pembahasan, maka dapat disimpulkan sebagai berikut:

1. Kecerdasan emosional dan karakteristik individu secara bersama-sama berpengaruh positif dan signifikan terhadap minat berwirausaha mahasiswa Manajemen Fakultas Ekonomi Universitas Tadulako. 
2. Kecerdasan emosional berpengaruh positif dan signifikan terhadap minat berwirausaha mahasiswa Manajemen Fakultas Ekonomi Universitas Tadulako.

3. Karakteristik individu berpengaruh positif dan signifikan terhadap minat berwirausaha mahasiswa Manajemen Fakultas Ekonomi Universitas Tadulako.

\section{Saran}

Berdasarkan hasil kesimpulan dari analisa yang dilakukan, maka penulis memberikan beberapa hal yang dapat diperhatikan dalam rangka meningkatkan minat berwirausaha mahasiswa Manajemen Fakultas Ekonomi Universitas Tadulako yaitu:

1. Sesuai dengan kesimpulan pertama yaitu kecerdasan emosional dan karakteristik individu secara bersama-sama berpengaruh positif dan signifikan terhadap minat berwirausaha mahasiswa Manajemen Fakultas Ekonomi Universitas Tadulako, maka saran yang dapat disampaikan adalah untuk kedua variabel tersebut yaitu kecerdasan emosional dan karakteristik individu perlu ditingkatkan lagi sehingga minat berwirausaha juga akan meningkat. kemudian bagi peneliti selanjutnya perlu memasukkan variabel-variabel lain selain dua variabel di atas.

2. Sesuai dengan kesimpulan kedua yaitu kecerdasan emosional berpengaruh positif dan signifikan terhadap minat berwirausaha mahasiswa Manajemen Fakultas Ekonomi Universitas Tadulako, maka saran yang dapat disampaikan adalah para mahasiswa dapat meningkatkan kecerdasan emosional dengan mengikuti berbagai kegiatan kemahasiswaan di kampus, mahasiswa bisa mengembangkan diri, dan mengelola diri dalam kegiatan-kegiatan kemahasiswaan. Mahasiswa juga haruslah mulai berani berwirausaha dengan berjualan barang maupun jasa, berkreasi membuat kerajinan tangan, membuka usaha baru, serta mengembangkan kreasi dan inovasi dalam organisasi kemahasiswaan.

3. Sesuai dengan kesimpulan ketiga yaitu karakteristik individu berpengaruh signifikan terhadap minat berwirausaha mahasiswa Manajemen Fakultas Ekonomi Universitas Tadulako, maka saran yang dapat disampaikan adalah para mahasiswa dapat meningkatkan karateriristik individu dalam hal berwirausaha melalui berbagai pelatihan yang berkaitan dengan pengembangan minat, hobi, kepemimpinan dan kemampuan berorganisasi serta berbagai pihak khususnya pihak kampus perlu membantu mahasiswa agar dapat meningkatkan karakter wirausaha seperti adanya pelatihanpelatihan atau seminar-seminar tentang kewirausahaan. Penanaman nilai-nilai karakter wirausaha dapat dilakukan dalam proses pembelajaran kewirausahaan.

\section{REFERENSI}

Ahmadi, A. 2009. Psikologi Sosial. Jakarta : Rineka Cipta.

Arikunto, Suharsimi. 2006. Prosedur Penelitian Suatu Pendekatan Praktik. Jakarta : Rineka Cipta.

Badan Pusat Statistik. 2015. Tingkat Pengangguran Terbuka (TPT). (http://www.bps.go.id) diakses tgl 5 Mei 2016.

Badan Pusat Statistik Sulteng. 2015. Tingkat Pengangguran Terbuka Sulawesi Tengah. (http://www.sulteng.bps.go.id) diakses tgl 8 September 2016.

Cooper, R.K. dan Sawaf, A. 2000. Excecutive EQ: Kecerdasan Emosional dalam Kepemimpinan Organisasi. Terjemahan. Jakarta : PT Gramedia Pustaka Utama.

Echdar, Saban. 2013. Manajemen Entrepreneurship Kiat Sukses Menjadi Wirausaha. Yogyakarta: CV Andi Offset.

Gibson JL dan Donnelly Jr., JH. 1996. Organisasi, Perilaku struktur dan proses. (edisi kedelapan), Alih Bahasa :Nunuk Ardiani. Jakarta: Binarupa Aksara.

Goleman, Daniel, 2003. Kecerdasan Emosional, terj. T. Hermaya, Cet. XIII, Jakarta: Gramedia Pustaka Utama.

Hakim, Thursan. 2004. Belajar Secara Efektif. Jakarta: Puspa Swara.

Ivancevich, John M., Robert Konospaske \& Michael T. Matteson. 2006. Perilaku dan Manajmen Organisasi, Jakarta: Erlangga.

Lupiyoadi, Rambat. 2007. Entrepreneurship from Mindset to Strategy. Jakarta: Lembaga Penerbit Fakultas Ekonomi Universitas Indonesia. 
Hasby, M.

Mahardiana, Lina. Abdul Wahid Syafar \& Andi Indriani Ibrahim. 2016. Persepsi Mahasiswa Fakultas Ekonomi Universitas Tadulako Tentang Perkuliahan Kewirausahaan Terhadap Minat (Intensi) Berwirausaha. PROSIDING Seminar Nasional dan Call For Papers RIEE 2016.

Mapiere, Andi. 1982. Psikologi Remaja. Surabaya: Usaha Nasional.

Meredith, Geofrey G. 2005. Kewirausahaan Teori dan Praktek. Jakarta: PT Pustaka Binaman Presindo.

Mudjiarto dan Wahid Aliaras. 2006. Membangun Karakter dan Kepribadian Kewirausahaan. Jakarta: Graha Ilmu.

Rivai,Veithzal. 2006. Kepemimpinan dan Perilaku Organisasi Edisi 2. Jakarta: Raja Grafindo Persada. Salovey dan Mayer. 1990. Emotional Intelligence, Imagination, Cognition and Personality 185-211.

Setiawati, Titik. (2013). Minat Berwirausaha Ditinjau Dari Lingkungan Keluarga dan Sikap Terhadap Peluang Usaha pada Mahasiswa Program Studi Pendidikan Akuntansi Fakultas Keguruan dan Ilmu Pendidikan Universitas Muhammadiyah. Skripsi Universitas Surakarta.

Siagian, S. P. 2002. Teori dan Praktek Kepemimpinan. Jakarta: Rineka Cipta

Singarimbun, Masri dan Sofian Effendi. 1989. Metode Penelitian Survei. Jakarta: LP3ES

Slameto, 2010, Belajar dan Faktor-Faktor Yang Mempengaruhi, Jakarta: Rineka Cipta.

Sugiyono, 2013. Metode Penelitian Bisnis. Bandung: Alfabeta.

Totok S, Wiryasaputra. 2004. Entrepreneur: Anda Merdeka jadi bos. Jakarta: Tridaharma Manunggal.

Winkel, W.S. (2004). Psikologi Pengajaran. (Terjemahan Toni Setiawan). Jakarta: Media Abadi. 